Sûfî spirituality fires reformist zeal: The Tablîghî Jamâ'at in today's India and Pakistan

\title{
Dietrich Reetz
}

\section{(2) OpenEdition \\ 1 Journals}

Édition électronique

URL : http://journals.openedition.org/assr/3715

DOI : $10.4000 /$ assr.3715

ISSN : $1777-5825$

Éditeur

Éditions de l'EHESS

Édition imprimée

Date de publication : 1 septembre 2006

ISBN : 2-7132-2093-9

ISSN : 0335-5985

\section{Référence électronique}

Dietrich Reetz, « Sûfî spirituality fires reformist zeal: The Tablîghî Jamâ'at in today's India and

Pakistan ", Archives de sciences sociales des religions [En ligne], 135 I juillet - septembre 2006, mis en ligne le 10 décembre 2010, consulté le 19 avril 2019. URL : http://journals.openedition.org/assr/3715 DOI : 10.4000/assr.3715 


\section{Dietrich Reetz}

\section{Sûfî spirituality fires reformist zeal: The Tablîghî Jamâ'at in today's India and Pakistan}

Typical of activist movements in South Asian Islam, the Tablîghî Jamâ'at combines the Sûfî principles of leadership with a reformist message. Therefore all the points I will be making here are not meant to contradict Marc Gaborieau's paper (published here in the same issue) but have to be seen in conjunction with it.

To those unfamiliar with the Tablîghî movement it should be pointed out that it represents a voluntary mass movement of lay preachers founded by Muhammad Ilyâs (1885-1944) in 1927 in the Mewat region around Delhi in Northern India. At the time it was contesting Hindu preaching activities among tribal Muslim converts. After the demise of British colonial rule the Tablîghîs branched out from there to all South Asian countries and more recently to all places where Muslims live. They could be called a pietist movement devoted to the so-called internal mission. They aim at reconfirming their Muslim co-religionists in their faith where they feel it has become slack, where Islam is not being correctly practiced or in danger of not being observed at all. For this purpose, they form groups of travelling preachers of usually up to 15 members, who head for a Muslim locality where they conduct door-to-door preaching. They invite people to come to the local mosque for prayer and for a religious sermon on the virtues of a pious life. This preaching activity would be undertaken either in the immediate vicinity or in far-away places, even in other countries. The formation of these groups of travelling preachers tends to become an end in itself as they seek to involve Muslims in ever growing number in their preaching for ever longer and more periods of time. The time spent in the movement, on the road, becomes a measure of the commitment to the ideals of Islam. The travelling scheme has more recently been complemented by efforts to organise permanent preaching groups at local mosques called the masjidwâr Jamâ'at (cf. Reetz, 2004).

In doctrinal terms, the Tablîghîs represent Hanafî Sunni Islam, although they remain open and attractive to all Sunni law schools and sects. While they proclaim to be inclusive, they practically share the inhibitions of Sunni radicals against Shî‘a Muslims and the Ahmadîya, a reformist sect considered by most 
Sunni Muslims as heterodox. They take their doctrinal lead from the purist South Asian Islamic tradition spawned by the Dâru'l-ulum Deoband in North India that came into being in 1863 . They are actively opposed by the modernist Jamâ'at- i Islâmî, created by Maulânâ Maudûdî (1903-1979) in 1941, which resents the seemingly apolitical attitude of the Tablîghîs. Opposition is also coming from the Barelwîs who represent an orthodox Sunni movement much closer to Sûfîinspired Islam, emphasising the centrality of pîr, shrine and grave worship. Barelwîs usually do not allow their mosques in Pakistan and India to be used by Tablîghîs and would not shy away from physical force to extern them, although rank Barelwî members occasionally do participate in Tablîghî activities. This is essentially a case of competition for influence among Sunni Muslims as the Barelwîs set up their rival organisation Dawat-i Islâmî led by Maulânâ Muhammad Ilyâs Qâdrî (b. 1950) and closely modelled on the Tablîghî Jamâ'at. ${ }^{1}$ Its propaganda activity has long relied on a similar course book - Faidân-i Sunnat elaborating the benefits of the norms and practices of the life of the Prophet (Ilyâs Qâdrî, 2000) although it is being reviewed at present. The Barelwis aggressively deny the Tablîghîs their Sûfî antecedents and brand them as Deobandî, or even Wahhâbî outfit (Qâdirî, 1969).

While the Tablîghîs are propagating a message of puritan, reformist Islam, they have partly preserved and partly developed an internal culture that is laden with Sûfi-inspired rituals. This culture apparently accounts very much for their cohesion. To everyone watching Tablîghî meetings and ceremonies, it becomes clear that the workings of the Tablîghî Jamâ'at both in their internal and external activities follow repetitive and carefully controlled rules often invoking a spiritual connotation. These set it demonstrably apart from other reformist movements. It is argued here that these rituals make the movement more accessible and popular in the true sense without necessarily making far-reaching compromise on the reformist message they are spreading.

I treat the Tablîghîs here as an activist Islamic movement. In this context activist movements are understood to be movements of Islam that came into existence since the nineteenth century and pursue mobilisation of believers through mass activism. In this sense they are seeking a public role for activist Islam akin to the role of other public bodies and organisations, creating an increasingly vocal public sphere of Islam, what I call elsewhere an Islamic sphere or Islamic sector (Reetz, 2006).

\section{Sûfî guidance and leadership}

It is understood that Muhammad Ilyâs' relationship with Sufism (tasawwuf) is grounded in the tradition of the Chishtîya Shaykhs. His connection with the

1. Cf. its website at http://www.dawateislami.net 
purist Deoband seminary was no obstacle to this influence. Thereby he shared the mode of operation of many leaders of reformist - islâh $\hat{\imath}$ - movements in the Indian subcontinent. They continued to operate as Shaykhs parallel to their reformist activities. They usually were initiated into several orders and they continued to grant affiliation (bay'at) to disciples. As the Deoband statutes put it, they regarded the principle of following the (sûfî) path, or tarîa, as the

... Consummation of good breeding, self-purification and spiritual traversing (sulvkke bâtin) within the auspices of researching Sûfîs and their well-tried principles (inferred from the Book and the Sunna), because, without this, moderateness in morals, stability of zest and ecstasy, internal insight, mental purity and observation of reality are not possible. It is obvious that this branch is connected with ahsân along with faith and Islam (Rizvi, 1980, vol. I, p. 329).

Sufism was acceptable to South Asian reformist Muslims if it was the "right" Sufism, based on the sharî'a, on the Qur'ân and the Sunna and did not follow heretic practices. The Deobandî reformists particularly rejected shrine and pîr worship, some also emphasised the rejection of singing and dancing. But in right measure and form Sufism was seen as an indispensable element of true Islam shaping a moral and pious character, a necessary supplementation for theological students, but also for salvation in general. Maulana Sayyid Abul Hasan Ali Nadwi exemplarily discussed the merits of correct Sufism in the light of Islamic reformism (islâh) in his book Purification and kindness or mysticism and initiation? (Tazkîyao-ahsân yâ tasawwuf-o-sulukk? 1989). His assessment is widely shared by the Tablîghîs. The book was recommended to me by an experienced Tablîghî functionary during interviews in Lahore in 2001 stressing its character as a guideline.

The Tablîghî elders enshrined this dichotomy in their famous six basic points detailing their "articles of faith". Point three has been called ilm-o-dhikr demonstrating the unity of religious knowledge and (Sûfî-inspired) ritual as they view it:

(3) Knowledge and remembrance of God (ilm-o-dhikr)

To spend some time in the morning and in the evening on gaining (religious) knowledge and remembering God. The common ritual of commemoration $(d h i k r)$ for every person consists of (counting the beads of) one rosary on reciting the third Kalima in the morning, one in the evening, and two each on invoking God's blessing (darûd) and asking God's forgiveness (istighfâr). If one is connected to a Shaykh one should follow his recommendation for prayer $(d h i k r)$. For (religious) education one should read [from the Tablîghî tracts of] 'The Virtues of Prayer' (fadâ'il-i namâz), 'The Virtues of Commemoration (of God)' (dhikr), 'The Virtues of the Holy Qur'ân' (fadâ'il-i Qur'ân), 'The Stories of the Companions of Muhammad' (bikâyât-i sahâbâ), "Reward of Good Deeds" (jazâa al-a'mâl). If the Qur'ân was not read previously it should be studied. For those qualified in religion (abl-i $\mathrm{ilm}$ ) (it is recommended to read) a book on virtuous deeds (kitâb al-'ilm-wal), on (religious) knowledge and beliefs (kitâb al- 'ilmwa-al-e'tiqâdât), on tradition (kitâb al-sunnan), on holy war (kitâb al-jihâd), on fighting (the Infidels) (kitâb al-maghâzî̀), on revolt (divisions in Islam) (kitâb al-fitan), on good behaviour (kitâb al-raqqâq), on what is right (and what is wrong) (kitâb al-amr bi'lma'rûf) (Ilyâs, 1997, p. 114ff). 
The quotation refers to the fact that the major book of the Tablîghî movement, the Fadâ'il-e a'mââl, a collection of hadith and pious commentaries written by the main ideologue of the movement, Muhammad Zakarîyâ (1898-1982; Zakarîyâ 1975 [1940]), contains a separate chapter on Dhikr, indicating its central importance for the movement. Judging from this text alone one has to assume that the movement condones, perhaps even encourages dual commitment of Tablîghî members to a Sûfî Shaykh and to the movement. But the text makes also clear that the movement in some form takes on the obligations of a religious guide, of a Shaykh itself, detailing the ritualistic commitments, the fulfilment of which would lead to salvation.

Among Tablîghî obligations, the emphasis on the reformation of one's own intentions, or niyyat, also seems to be a highly Sûfî-inspired element. Point 5 of their 'articles of faith' reads:

(5) Correction of intention and conduct (tashîh al-niyyat wa al-khalâs)

All this work should be undertaken for the glory of God and for one's self-improvement

(islâh). Don't turn the gaze to any external aim. Also do not pay attention to effect and result (of your action) (Ilyâs, 1997, p. 114ff).

From this, a self-effacing attitude is derived as their main instrument of encountering doubters, non-believers or non-Muslims. They would always first blame themselves for failing to properly explain their position. Internal selfreformation becomes key to turning into a genuinely pious person, improving your chances for the hereafter and generally reforming society and life in the spirit of Islam. Rituals such as Dhikr and $d u^{\prime} \hat{a}$ but also pious deeds are supposed to help the Tablîghî improve and purify his niyyat.

It is perhaps worth noting that books such as the Fadâ'il-i a'mâl take on a ritualistic function in defining the movement. A special status is also accorded to the reports on the life of the Tablîghî elders. They are written in the format of hagiographies (tadkira) well known from life sketches of Sûfî saints in connection with certain shrines. There are biographies written about the first three leaders of the Tablîghî Jamâ'at, Muhammad Ilyâs, Muhammad Yûsuf (19171965) and In'âm-ul-Hasan (1918-1995), some of them under the title of Tazkîrâ (Bijnaurî 1980; Hasan 1996), others as Sawânih-i Hayât (Nadwî 1980 [1946]; Shahîd Sahâranpûrî 1997; Hasanî 1982). And there are the Malfâzât, the sayings of the saints, attributed in this case to Maulânâ Ilyâs and Maulânâ Yûsuf (Nu'mânî 1993; Shâh Qâsimî 1994). One cannot escape the Sûfî connotations of such categories of literature, also when considering that some of these biographical works have obtained ritual meaning in the Tablîghî movement. Especially Ilyâs' biography written by S.A.H.A. Nadwî (1980) is widely read in preparation of new Tablîghîs for their first preaching tours.

The question today is what is left of this influence in the Tablîghî Jamâ'at? When I am looking for Sûfî influence on principles of leadership I would distinguish between informal and formal observance of a Sûfî style of leadership. Informal 
observance might be characterised by personal, charismatic and moral authority, based on chastity and sanctity as recognised by others, on erudition in the formal principles and sources of Islam, on the knowledge of the Qur'ân, hadith and the Sunna, of the internal culture of the movement and its guiding moral principles.

Formal observance might refer to the initiation of disciples creating a personal attachment of followers with their leaders through bay'at. I discussed this issue with some of my informants during my field research. ${ }^{2}$ It appears that Tablîghî leaders in India and, to a lesser degree in Pakistan, continue acting as a Shaykhs initiating disciples into their favourite orders. I received confirmation of this practice from members of the inner circle of Tablîghî activists based at Aligarh. Particularly In'âm-al-Hasan was reported to have administered bay'at to groups of Tablîghî activists on the sidelines of their annual congregations by throwing a peace of cloth over them. This mass bay'at was nevertheless a closed affair. Workers who wanted to get this favour granted had to intimate the leadership of their intention in writing in advance. The composition of the group was carefully screened and participation was granted only selectively. The criterion was loyalty and allegiance to the Tablîghî Jamâ'at. I was told that In'âm-al-Hasan used offerings by his disciples to finance a substantial part of the running expenses of the Tablîghî centre (markaz) in Delhi.

Another direct form of Sûfî leadership is embodied in the direct connection of Tablîghî elders with the Meo tribes living in India around Delhi. It was from the Mewat region that the Tablîghî movement originally took its beginnings. The Meo tribesmen regarded Ilyâs and also his father as their Shaykh and Pîr to whom they feel they still owe allegiance. At the annual congregations of the Tablîghîs in India and Pakistan, Mewatis always constitute a sizeable delegation. They usually make it a point to seek a special interview with one of the central leaders for whom they hold special reverence to receive his blessings. Here Maulana Muhammad S'âd (b. 1965), one of the two current Amîrs, as the most direct heir of Ilyâs being his great-grandson plays the central role. When he visits Pakistan for attending the annual congregation there, he also grants special audiences to the Pakistani Mewatis who migrated as refugees in sizeable numbers to Pakistan at partition. Many of them settled near Lahore in Kasur district.

A third reference may be the self-conscious portrayal of the central leaders of the Tablîgh, primarily in India, as belonging to the Chishtîya sub-group or silsilâ of the Kândhalawî. This was manifested by the publication of a directory of members of this clan and silsilâ by a Tablîghî elder, Maulânâ Ehteshâmu'lHasan (1996). There he pointedly discussed the "conditions of the Shaykhs from Kândhalâ". This refers to all those related to Maulana Ilyâs and Muhammad

2. The data mentioned here refer to interviews with Tablîghî respondents in field research on case studies at Aligarh University and the Tablîghî annual congregation in Bhopal (India) in December 2000 and January 2001, and at Lahore University of Management Sciences and the Tablîghî annual congregation at Raiwind near Lahore (Pakistan) in October-December 2001. 
Zakarîyâ who called themselves Kândhalawî after their place of origin Kândhalâ in the North Indian state of Uttar Pradesh. Zakarîyâ was Ilyâs' nephew and became the main theoretical head of the movement by writing dozens of religious tracts which are still widely used in the movement. He also showed special inclination towards Sufism. The two lineages of Maulânâ Ilyâs and Muhammad Zakarîya started intermarrying consciously since 1935 when the two daughters of Zakarîya married the two future Amîrs of the Tablîghî Jamâ'at, Maulânâ Yûsuf and Maulânâ In'âm-al-Hasan following the well-known pattern of South Asian family clans. Between them, they now control most of the leadership positions of the Tablîghî Jamâ'at at the Nizamuddin Markaz and at the Islamic school of Sahâranpur. ${ }^{3}$ Followers of Maulana Zakarîya over the years have independently formed into a separate silsila spreading throughout the Islamic world wherever Indian Muslims migrated. Notable examples are Pakistan, Bangladesh, Burma, South Africa, Saudi Arabia and Britain. His network of disciples (khulafâ) fused Islamic schools in the Deobandi tradition with strong participation in Tabligh activities, personal loyalty and spiritual devotion in the Sûfî tradition. A recent directory lists 110 initiated khulafâ (Mutâlâ, 1986).

On a lesser scale, Sûfî practices by Tablîghî elders also continue today. Although the Tablîghî leadership tried to switch to a less personalised style of functioning after the demise of in'âm-al-Hasan, it is known of Maulânâ Zubairul-Hassan (b. 1951), a grandnephew of Maulana Ilyâs, that he continues to initiate disciples. In Pakistan, among the Tablîghî elders, it is Maulânâ Jamshed Ahmad, who is doing the same. He is the follower of Maulânâ Ashraf Alî Thânawî (1863-1943) who was both a writer of reformist tracts in the Deoband tradition and a Shaykh of wide influence. But apparently these practices are not undisputed. Several informants referred to a decision taken collectively by Tablîghî leaders in India and Pakistan some years ago, that Tablîghî elders should refrain from using Tablîgh activities to extend their influence as Shaykh. This was portrayed as a form of voluntary self-restraint, typical of Tablîghî culture. But the fact that it was considered necessary to take such a decision is remarkable. It shows that there was apparently some conflict of interest. It seems that it was feared pîr-murîd relations could potentially "corrupt" the "pure" Tablîghî message. As for the selective acceptance of Sûfî practices on part of some elders, it also seems to indicate that within the inner circle of elders, much more is condoned or encouraged - if it is in the interest of the movement - than is formally acknowledged to a wider circle of activists.

\section{Self-organisation and interaction in the style of a Sûfi order}

The central leadership figure in the Tablîghî Jamâ'at is the amîr. This is not diminished by the fact that the Tablîghîs themselves rather emphasise the shûrâ

3. Interview with Maulana Sayyid Muhammad Shâhid Sahâranpûrî, 2 March 2004; cf. SHAHID Sahâranpûrî 1991: 10, 31. 
and the consultation principle as its key element of functioning. But the formation of the shîrâ both at the central level and in local centres (marâkaz) cannot obscure the fact that some are more equal than others in this system. It is obligatory for all Tablîgh activities that an Amîr is selected or elected at any stage in any meeting. The amir principle embodies different and competing traits of political culture. ${ }^{4}$ From one perspective, it reflects western and democratic influences. Every activist, belonging to what I call the regulars for meeting a certain number of obligations, is encouraged to become amir at one stage of his membership. Without taking on these obligations at least once, the regular is not understood to have completed his formation as a pious Tablîghî. While apparently there truly is a sometimes broad-based consultation process on who would become amîr, it is equally clear that crucial positions are filled through nominations. These are decided in a small elite leadership circle to whom not many elders even have access. The amir has the last say when leadership councils are formed in important places or leadership jamâ'ats are being created for special tasks of supervision. These patriarchic beginnings are reinforced by the internal culture surrounding the position of amir. It is clearly spelled out that an amîr at any level of the organisation can demand unquestioning obedience. It is strongly discouraged to ask questions and to make fuss about unclear issues. While a Tablîghî is on jamâ'at, as the term goes for preachers out with their groups in the path of Allah, he is not supposed to do anything without permission from his amîr, including going to toilet, or leaving the group. He should ask no questions, not even harbour any wish to ask a question in his heart, which is enshrined in the four things not to do.

But what is more important in terms of the Sûfî antecedents of the movement is the way by which Tablîghî etiquette obliges the Amîr to rule by moral example. $\mathrm{He}$ is supposed to share all menial work during travel, including cooking or cleaning, including the toilet. He is supposed to lead by his sincerity and knowledge. Tablîghî elders are revered for their pious character - and of course for their knowledge of Islam and of the books of the Tablîghîs. The Amîr for all practical purposes is a Shaykh showing his fellow preachers the path of Allah. $\mathrm{He}$ is moulding them, educating them not only in Islam but also in Islamic and Tablîghî etiquette, in civil etiquette in general. While being on tour, Tablîghî preaching groups in special sessions discuss with their Amîr the correct ways of praying, fasting, but also eating or sleeping. In this sense, it could be argued the whole movement is a collective Shaykh for the new lay preachers joining its ranks. The movement, or more precisely the body of regulars who devote much or most of their life to its activities, have set themselves the task of bringing new followers in stages to a pious life. They are preparing their members for the hereafter by deeply intervening in their religious attitudes and personal behaviour. They see

4. Political culture is simply understood here as the ways of how things are being done that can be traced back to one or the other political tradition. 
to it that the ordinary member changes his life style; that he dresses simple in the way of the Prophet; that he sleeps and eats in the way of the Prophet and his companions; that he approaches life in all its facets in the way of the Prophet. It seems clear that the example of the Prophet for them holds a larger than life, a mystical fascination. But for them, it is also a consequential reformist attitude as it brings out a true Islamic life style in new adherents, as they are subjected to islâh.

Particularly for the regulars, life in the Tablîghî Jamâ'at is so full with daily ritualistic obligations that it resembles more life in a monastic order than an activist Islamic movement. Ascetic features start dominating the whole of your life activities. You start changing your cloth donning the shalwâr-kamiz and shunning any western clothes. You forgo any comfort while on tour, carrying your own bedding, cooking utensils. You spend money while on tour on the level of the poorest fellow preacher. With time passing, you will stop watching television for entertainment and ultimately remove the TV set from your house. You will stop going to the pictures and of course refrain from gambling and drinking alcohol. And you are ascending on the ladder to Tablîghî perfection by the amount or percentage of time you spend on its activities. Gradually, many regulars are drifting out of this world into another reality. There is also a category of full-timers who are called muqim. They reside at the centres, the marâkaz, although they have to look after their family and income, which they do in clearly defined intervals like once per week or per month. They have almost fully renounced worldly life in favour of working for the message of Allah to be spread to the greatest effect. There are different categories of the muqim forming a clear hierarchy. According to informants, there are about 300 muqim at the Raiwind centre near Lahore, Pakistan, and perhaps up to ten at every local marâkaz. The elders who form part of the decision-making council or shûrâ enjoy the highest authority. Some of them are teachers (Maulânâs) at the Madrasa of the Tablîghî centre. Even the eldest among the shûrâ members are not spared the obligation to perform the excruciating long variation of the preaching tour, the grand chillâ, consisting of three chillâs per fourty days, regularly. There are also younger muqîm who have their family life continuing and live at the centre in intervals. They are usually much advanced on the ladder of commitments having served a large number of travelling preaching terms; sometimes they are related to the elders like being their sons. They are perhaps groomed - or aspiring - for future leadership positions within the movement. A third category of muqim consists of regulars who serve a long preaching term, such as a grand chillâ, a seven-month or a one-year tour. They live as interns at the centre as part of their term, welcoming and chaperoning guests or incoming Tablîghîs, running errands for the elders or serving as ushers, forming sort of a lower rung of leadership and administration at the markaz. It is obvious that one can here also discern modern influences of business organisation and public administration.

But in a certain way the marâkaz also resemble Sûfî hospices (khânaqâh). A tour of the Tablîghî centre at Raiwind is very telling in this respect. The huge 
compound represents a sprawling religious city with a huge free kitchen or langar provided for its resident inmates, a mosque, halls of residence and prayer, administration buildings and a graveyard. They establish a kind of Islamic microcosm insulated from the real world in many ways, a kind of Islamic socialism, the embodiment of the Islamic ideal of life of the early Islamic community formed by the Prophet and his companions. The food for the residents is free. Food items and provisions sold to incoming and outgoing Tablîghî travelling preachers are sold at subsistence prices. No salaries are paid to residents. Praying is done collectively - and it is compulsory with guards calling those lagging behind. Regular religious talks - bayân - complement the day leaving little room for personal affairs. Everyone sleeps on the ground in huge halls on his mattress.

\section{Sûfî traditions in Tablîghî rituals}

Sûfî influences can be discerned at various levels of Tablîgh activities.

They directly relate to practices and rituals known to be particularly favoured by Sûfî-Islam, such as Dhikr, $d u^{\prime} \hat{a}$, and bay'at. Here belong practices at their congregations - ijtimâ' - used not only to convey knowledge - 'ilm - but also to transmit grace, or barakat, to the believers. The ritual of devotional seclusion or chillâ as interpreted and practiced by the Tablîghîs also has to be seen in this context.

They indirectly concern the very structured and ritualistic internal culture of the Tablîghîs that places upon followers obligations not necessarily identical with Sûfî rituals but fulfilling a similar purpose of ensuring that members travel the path to perfect piety guided by the elders.

As can be seen from the quotation in the beginning, Tablîghîs consider the regular practice of $\mathrm{Dhikr}$ as an essential element of their internal reformation, of the purification of their intentions. The regulars in the movement have clearly internalised this approach. Respondents who worked in the comparatively modern environment of a reputed Business School would use their free time to make silent Dhikr whenever they can. When we were driving from the School to the compound where the annual congregation was held, my informant would start driving the car not without an appropriate $d u^{\prime} \hat{a}$ (prayer) for auspicious travel. When the Tablîghîs are on the road in their preaching groups, they will discuss techniques of Dhikr and exchange most auspicious $d u^{\prime} \hat{a}$. Before and after eating, at bedtime, the more aspiring Tablîghî under the close gaze of his fellow-preachers will miss no opportunity to make the appropriate $d u^{\prime} \hat{a}$.

When looking at the institution of the Tablîghî chillâ, which is the technical term for a fourty-day preaching tour that is obligatory once a year, it becomes obvious that going out with up to fifteen other men can hardly be called solitude. 
So apparently there is no meaning left of the Sûfî devotional seclusion. Yet, interviewees told me repeatedly of their experience with these and other longer tours: it is this seclusion in the group, which becomes a test of character, devotion and piety. While on tour, members are not allowed to leave the group or even make phone calls to the parents who at times are much perturbed about the whereabouts of their boys. An experienced Tablîghî elder from Pakistan told me that he had been together with another colleague on a grand chillâ, that is, four months, about which experience he remarked that you get to know each other very well and have to endure the presence of other Tablîghî members for such long periods of time without problems or tension.

The habit of the Tablîghîs to stay over night in mosques while travelling on their preaching tours may also be rooted in Sûfî practice. Occasionally ' 'ulamâ' from the same Deobandi tradition in which the Tablîghî Jamâ'at is rooted criticise the Tablîghîs for this practice. The Tablîghî elders usually defend it with reference to the pious practice of $i^{\prime} t i k \hat{a} f$, the ritual seclusion in the mosque during the fasting month of Ramadân. This reference is apparently meant to show that such action is permissible and not in violation of the Qur'ân and the hadith. Considering the special connection of the Tablîghî founder with the Chishtî order, it is interesting to note that some Chishtî Sûfîs like Gisu Daraz (d. 1422) stressed the importance of $i{ }^{c} t i k \hat{a} f$ in various connotations, largely in the meaning of seclusion for self-purification. ${ }^{5}$ Also here the Tablîghî appropriation of this custom has considerably moved away from the original meaning.

A special remark has to be inserted here about the role of pious dreams and their interpretation. Dreams are given a special significance also in the Tablîghî movement. They are used to give added legitimacy and authority to da $w a$. When visiting the weekly proceedings of the rather powerful Lahore shûrâ at their head mosque, I encountered a determined effort by the present elders to give me concerted $d a^{6} w a$, although strictly speaking, the Tablîghîs don't make the task of preaching to non-Muslims explicit. One of the elders used the opportunity to emphatically impress upon me the virtues of Tablîgh, with reference to a pious story central to which was a dream and providence shown in it. He narrated a story where a poor Tablîghî member could not go on the planned foreign preaching tour, which generally Tablîghîs must finance individually, because he could not present his money draft to the selection committee, while the cut-off date was nearing after which he would be excluded from the tour. So he prayed to Allah constantly that a miracle might happen. In the meantime, a merchant in Karachi had a dream where Muhammad directed him to go and give a certain amount of money to a person by a certain name in Kohat, in the Pakhtûn tribal area in the northwest of the country. After he had had the dream twice, he

5. Cf. the Chishtîya website http://www.chishti.ru/chishti_sufiorders.htm, downloaded 24-06-05. 
became worried and started to seek the person out. When he went to Kohat, the poor Tablîghî was sitting at the local mosque, praying, weeping and wailing that he had no means to go out on the path of Allah. Then the merchant approached him, inquired about his name and gave him the money as he had been instructed. But the poor Tablîghî would not take the money before the 'ulam $\hat{a}$ ' would certify that it was right to accept this gift for this purpose. ${ }^{6}$ The story clearly reveals Sûfî antecedents. References to dreams in which the Prophet appears and gives instructions have a long tradition in South Asian Islam, also among reformists who as was mentioned earlier never fully renounced their Sûfî heritage. Such dream is also attributed to the founder of the movement, Ilyâs who hinted that he had received the message and method of Tablîghî from the Prophet (Nu'mânî, 1993). The controversial founder of the Ahmadîya sect, Mirzâ Ghulâm Ahmad (1839-1908), did the same. He was famously preceded in this by Shâh Walîullâh who is nowadays regarded as the father of the Indian school of Islamic reformism (islâh) and was said to have shared views and influences with Abdul Wahhâb. Walîullâh claimed that in his dream he had been presented with a pen that belonged to the Prophet. He even alleged that in this way the Prophet himself administered bay'at to him (cf. Rizvi, 1980, vol. I, p. 2).

It is also interesting to note that the Tablîghîs in all their reformist fervour have developed a particular liking for auspicious fragrances (attâr). Near major Tablîghî centres as much as near Deobandi Madrasas such as the dâru'l- 'ulûm in Deoband proper, there are shops found trading in the fragrances, supposedly favoured by the Prophet. The Tablîghîs very much share this custom. Fragrances are selected for particular occasions such as the season - winter or summer -, for treating emotional or physical ailments. The use of these fragrances is regarded as auspicious as it is supported by traditions (hadith) linking this custom to the Prophet and his companions.

And it is not least the ijtima $\hat{a}^{\circ}$ or huge congregations where rituals are observed that betray Sûfî influences. The most prominent of them is the concluding prayer of supplication, or $d u^{\prime} \hat{a}$, at the annual congregation. It takes place on the last day and concludes the meeting. It is transmitted by huge loudspeaker systems all over the congregation ground. It is the one event that attracts the largest number of participants. Not only would the delegates to the congregation attend it. Also many chance visitors, sympathisers and local Muslim people come for this special occasion. This event easily draws participants up to a million and more. They come dressed in their finest, move in on bus, bike, tractor, or on foot. They clearly regard it as an auspicious event transmitting an enormous amount of barakat. Suddenly the congregation site becomes a huge shrine and the preacher of the $d u^{\prime} \hat{a}$ its pir. The final $d u^{\prime} \hat{a}$ is always given by a prominent Tablîghî leader, in India and Pakistan very often by Maulana Zubair. He is

6. So narrated to me at Bilâl Park mosque on November 5, 2001. 


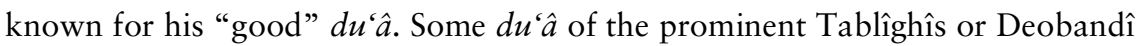
elders are attached to printed memoirs, biographies or published separately. The $d u^{\prime} \hat{a}$ is also a political affair as it is closely watched who and what is mentioned in this prayer. It was noted with particular concern by many radical Islamists, that the Tablîghî elders failed to mention the talibân after their downfall from power by the American-led war following September 11, 2001.

Then there is a wide grey area of ritualised behaviour where the ritual is not necessarily recognisable as being of Sûfî origin but where the ritualistic conduct resembles efforts to establish a sort of "Protestant church" with its own attractive rituals; transmitting as much barakat as the established and reviled conventional shrine and $p \hat{\imath} r$-related activities.

The participation in the preaching tours is at the centre of these efforts. Several respondents told me about the difficulties followers might face when deciding to go out on a long preaching tour, notably with financial and family matters. But they will then share their experience with you about the good or endless barakat all this brought them, as in the end in spite of seemingly insurmountable difficulties things miraculously settled all by themselves. If sons previously had no employment, the absence of their father forced them to seriously seek some. If wife and mother were constantly quarrelling, they were forced by the husband/son's absence to mend their ways. If in an extended family, a good earning Tablîghî breadwinner was previously thinking of buying a second car he - and the whole family - would cut down on expenses required to sustain the Tablîgh activities, leading a much more contented life afterwards on a lesser scale. Wives and sons would turn the Tablîghî way, rendering suddenly the huge sacrifice in time and money much more acceptable in the family.

The repeated assertion of my informants was that, of course, there were those who were wavering and found it difficult to go the way of Allah. But those who were ready to make sacrifice would be rewarded not only in the hereafter, but also here and now spiritually.

The scope of this paper does not allow detailing the Tablîghî internal culture and their ritualistic attitude in full. Suffice it to note the strict rules they have established for their various schemes of activities. For instance, there is a grid of rules transmitted to every new Tablîghî to guide him on the Tablîghî preaching tours. There are four things to do (da'wa, ta'lim, namâz-o-zikr, khidmat), four things to do less (sleeping, eating, talking, going outside the mosque while on tour), four things not to do (asking unsolicited questions, not harbouring those even in your heart, excessive expenditure, not taking anything without permission) and four things to refrain from (rejection, criticism, competition, pride). There is a highly structured and fixed way of conducting the tour itself; there is a ritualistic way of addressing each other, and particularly elders or the Amîr. 
During the annual congregations, rituals have been introduced, designed to spread the reformist message while the proceedings have become ritualistic themselves. This starts with the major religious speeches, or bayân, forming part of any Tablîgh meeting, where religious anecdotes mixed with references to the Qur'ân and the hadith are being recounted to inspire listeners, a kind of religious pep talk. At the big congregations there is evidently a hierarchy of speakers for these bayân, some of which are considered much more effective and auspicious than the others. The youthful radiance and pop star charisma of Maulânâ S'âd inspires elation and hope of barakat in his listeners as I witnessed myself at the Bhopal congregation in January 2002. So do the tales recounted, some of which make free use of miraculous incidents, either narrated in the Qur'ân and the Traditions or related by the elders as referred to above in the case of the dream.

The annual congregations now for many years have been featuring mass marriages. They were originally designed to propagate simple marriage ceremonies in line with the sharî' $a$, as many South Asian families bankrupt themselves in lavish marriage feasts, the Valima dinners, and also in paying the huge bride money typical of South Asia. Now it is considered particularly auspicious to participate in these mass marriages (nikkâh) and the numbers of participants are swelling from year to year. About 150 marriage parties attended the ceremony at the Bhopal congregation in January 2002. At the Raiwind congregation in October 2002 there were so many marriage parties that the $d u^{\prime} \hat{a}$ had to be administered in several groups so that the general proceedings would not be disrupted. A small number of such Tablîghî marriages is being conducted at local marâkaz of some status, such as in Delhi or Lahore. All formalities would be regulated beforehand with the local qâzî. The bridegroom and the bride's representative $(w a \hat{l} \hat{\imath})$ would participate at the congregation. Their names and the amount of dowry (mehr) fixed to be paid at the time or in the event of separation would be read out.

It is again barakat, which followers expect to flow from this ceremony in abundance.

\section{Sûfî spirituality in Tablîghî philosophy}

If the Tablîghîs occasionally stand accused of exoteric practices and a lack of esotericism (Gaborieau), I believe a digression on the way the Tablighî philosophy is being shaped may help mitigate this impression. In order to revive the Tablîghî message all the time, there is a constant attempt on the part of the Tablîghî leadership to keep their message evolving, so as to satisfy also the inquisitive and intellectually demanding members. Some key expressions and references are regularly reinterpreted to make them appear as if there is a new accent or meaning. One example of this is the emphasis on imân or faith and the way this is being 
interpreted. My impression is that the more devotional leaders of the Jamâ'at make it a particular reference point stressing that all they are doing is to create the perfect religious man (insân-e kâmil) - a Sûfî connotation for the Prophet. ${ }^{7}$ The emphasis on faith is to show that it is an internal quality, which is required and which the whole movement revolves around. Without faith there is no barakat to be expected from prayer or other externalist practices. One Tablîghî intellectual explained to me the special meaning of the causative relationship between imân (faith) $\rightarrow$ ibâdat (worship) $\rightarrow d u^{\prime} \hat{a}$ (prayer for supplication) $\rightarrow$ and Allab's help, as the various stages for the Tablîghîs to get help from God. Maulana Muhammad S'âd, the great grandson of Muhammad Ilyâs and one of two current Amîrs of the Indian chapter of the movement, which is also in charge of global coordination, explained this interconnection at the 2002 congregation in Pakistan and it was understood to reflect his intellectual and religious acumen and capacity to develop the Tablîghî legacy further. He particularly stressed the connection between imân and ibâdat, that it is not enough to know about the rules of Islam, but their practice has to come from your heart with sincerity; between ibâdat and $d u^{\mathfrak{a}} \hat{a}$, that it is not enough to come for prayer without actually regularly worshipping God, as only then you will get Allah's help. While this is from one perspective an approach that all ideological movements employ, it is apparently not without meaning that the internal changes in man the movement wants to stimulate are the centre of the Tablîghî's concern, where the way of personal purification and piety is the only way to God, which could be understood as an application of the Sûfî concept of individual Union with God.

\section{Contrasting influences}

The overview of the Sûfî connotations in the Tablîghî Jamâ'at has to be contrasted with other factors as well. One of them is the influence of the country of operation. It is felt that India allows more leeway for the display of the Sûfî characteristics of the movement than Pakistan, for instance. Several respondents remarked that the character of the different branches and leaders can be distinguished. The Indian leaders are understood to be more spiritual and demonstrably pious. The Pakistani leaders and the movement led by them is more organised, disciplined and one could even say militant or dogmatic - in terms of doctrine and practices. This may perhaps be an undesirable generalisation, but it seems indicative of trends.

The preaching groups usually appoint a guide with local knowledge (râhbar). Indian respondents spoke of incidents where Tablîghîs on their tours relied on the help of pious Hindus serving as guides and leading them to houses of Muslims,

7. This reference was made by Maulânâ Fahîm Sahib, who teaches at the Madrasa attached to the Tablîghî centre, on 11 December 2002 in Lahore - DR. 
especially where Muslims were in a minority. But it was clear that Hindu neighbours occasionally endorse the participation of their Muslim neighbours in the movement on grounds of a shared vision of piety.

In media, the continued activity of Tablîghî leaders as Shaykhs granting bay'at is not an issue, it is not discussed but apparently still present. No particular conflict is seen in this. In Pakistan, respondents on the contrary emphasised the clear-cut division and that the movement should be kept free from these activities.

Another factor to be taken into account is the opposition of Tablîghîs to shrine and pir-related rituals. Interviews at the Nizamuddin shrine in Delhi near the Tablîghî headquarters revealed that many Tablîghî leaders used to visit the shrine and pray there. But they would never buy flowers to make an offering at the shrine. While ordinary Tablîghî members still continue to visit the shrine, leaders have now stopped doing so. Relations have become even more tense with attempts by the Tablîghî headquarters to dominate the local area historically structured around the Nizamuddin shrine. The Tablîghî leadership stands accused of making concerted efforts to push out non-Deobandi Imams from the local mosques replacing them with their own candidates.

The Barelwîs, representing the organised Sûfî-Islam, which by no means exhausts the large and very diffuse sector of popular Sûfî-oriented Islam, have shown growing resentment of Tablîgh activities, seen as a competition making inroads in their territory of control. The Tablîghîs accuse them of corrupt practices referring to their massive collection of money at the shrines. The interviewees at the Nizamuddin Shrine retorted that, if anyone was corrupt it was the Tablîghîs accusing them of hypocrisy. It was not clear the Nizamuddin shrine keepers would contend where the money for the construction of the huge concrete Tablîghî Centre in the neighbourhood had come from. The Tablîghîs, they contended, would also completely ignore social issues, not looking after destitutes in the area, whereas the Nizamuddin shrine feeds a large number of poor people in the langars. Tablîghî would never donate a single rupee when visiting the shrine.

Summing up, one could say that the Tablîghî Jamâ'at represents a typical amalgam of reformist Islam in the South Asian variety. It has strong Sûfî roots, which it prefers not to acknowledge publicly. Sûfî references and principles are used for the mobilisation and control of adherents. The personalised Sûfî style of functioning with its connotation of piety and spirituality is found useful for its more direct impact on the psyche and conduct of individual Muslims. It allows Tablîghî leaders to mould adherents to an extent where their personal identity and behaviour are radically redefined. This could be an explanation why secular critics often accuse the Tablîghîs of brainwashing techniques. 
It will be difficult and perhaps not even advisable for the Tablîghî leaders to completely rid the movement of Sûfî influences. They will want to use this personalised style of leadership for effective control. Also there are the problems of growth. With the attraction of large masses in both India and Pakistan, and beyond, society at large with its variety of social, cultural and religious styles enters the movement. This increasing diversity makes it more difficult to impose a unified mode of operation. Traditional influences compete with modern objectives. The movement's elite is increasingly contemplating Tablîgh activity in terms of strategy, goals and achievements, of territories covered or not sufficiently worked upon. By this it grows more ideological, trying to maximise control of society in its own way. This ambiguity will not go away; rather we may be witnessing increased tension between its utilitarian aspects and its pietist beginnings.

It appears that the Tablîghîs have indeed adapted the Sûfî heritage to their needs. The symbolism and rituals are designed to help the adherents on the path of Allah to prepare themselves for the hereafter. They become endowed with an auspicious meaning, with the capacity to mediate between the follower and God. They may not be an initiatic Sûfî order. But they have internalised the Sûfî legacy to an extent where it naturally flows into other areas and forms. And, compared with other reformist groups of Islam in South Asia, they seem to be by far the most pietist and devotional, relying on internal perfection of their religious personality. In this sense I would call them a true modern incarnation of Sûfî aspirations.

Dietrich REETZ

Centre for Modern Oriental Studies - Berlin

\section{Bibliography}

BIJNAURî Azîzurrahmân, 1980, Tadhkira-yi Amîr-i tablìgh Maulânâ Muhammad Yûsuf (Urdu - Life sketch of the Leader of the Tablîghî Jamâ'at, Maulana Muhammad Yûsuf), Bherâ, 'Unnûrain Akâdmî.

ILYAS Muhammad, 1997 (1980), Irshadât wa Maktûbât (Urdu - Letters of instruction, compiled by Iftekhârhusain Farîdi), Lahore, Urdû Bâzâr (Numerous editions).

ILYAs Qâdrî Muhammad, 2000, Faidân-i Sunnat (Urdu - The beneficence of the Sunna), Karachi, Maktaba-ul-Madîna.

HASAN Ehteshâmu'l, 1996, Tadhkira-e Islâf- halât-e Mashâ’ikh-e Kândhalâ. Part I (Urdu - Life sketches and stories of the ancestors and Shaykhs of Kândhalâ), Kândhalâ, Dâr al-Ishâ'at.

HaSANI Sayyid Muhammad, Sani, 1982, Sawânih hadrat Muhammad Yûsuf Kandhalâwî (Urdu - On the life of Muhammad Yûsuf ibn Muhammad Ilyâs Kândhalawî al-Dihlawî), Lucknow, Maktaba Dâru'l-'Ulûm. 
MutÂLÂ Muhammadf, 1986 (1406 AH), Maulânâ Muhammad Zakarîyâ aor un kê Khulafâ-e Kirâm (Urdu - Maulânâ Zakarîyâ and his venerable disciples), 2 vols., Bury, Dâru'l-ulûm al-Arabîya al-Islâmîya.

NADWI Sayyid Abû'l-Hasan Alî, 1980 (1946), Hadrat Maulânâ Muhammad Ilyâs aur unkî dîn̂̀ da'wat (Urdu - Ilyas and his call for religious renewal), Delhi, Idâra Ishâ at-i Dînîyât.

NADwî Sayyid Abû'l-Hasan Alî, 1989, Tazkîya-o-ahsân yâ tasawwuf-o-sulûk? (Urdu Purification and kindness or mysticism and initiation?), Lucknow, Majlis-e Tahqîqâto-nashrîyât-e Islâm.

NU'MANî̀ Muhammad Manzûr, 1993 (1950), Malfûzât Shâh Muhammad Ilyâs (Urdu Sayings of Muhammad Ilyâs) Lucknow, Al-Furqân Book Depot; numerous editions.

QÂDIRî Ârshad-ul, (1969), Tablìghî Jamâ'at: haqâ'iq wa ma'lûmât (Urdu - The Tablîghî Jamâ'at: Facts and Information), Lahore, Maktaba Nabwîya [n.d.].

REETZ Dietrich, 2004, "Keeping busy on the path of Allah: The self-organisation (intizâm) of the Tablìghî Jamâ'at", in Daniela Bredi, ed., Islam in South Asia. Roma, 2004 (Oriente Moderno, 84:1), p. 295-305.

REETZ Dietrich, 2006, Islam in the Public Sphere: Religious Groups in India (1900-1947). Delhi, OUP.

Rizvi Sayyid Mahboob, 1980, History of the Dâr al-'Ulûm. 2 vols., Deoband, Idâra-e Ihtemâm.

SHÂH Qâsimî, MufTî Rôshan, 1994, Malfûzât wa Iqtibâsât (Urdu-Sayings and Quotations of Muhammad Yûsuf), Delhi, Idârâ Ishâ'at-i Dînîyât, 1994.

SHÂHID Sahâranpûrî, SAYYID Muhammad, 1991, Hadhrat Shaykh kî tîn (marhûma) Ėâhibzâdîyẫn (Urdu - The three [deceased] daughters of Shaykh [Zakarîyâ]). Sahâranpûr, Kutub khâna Ishâ'at 'Ulûm.

SHÂHID Sahâranpûrî, SAYYID Muhammad, 1997, Hadrat Maulânâ Muhammad In'âm alHasan Kandhalâwî, (Urdu) Sahâranpûr, Maktaba Yadgâr-i Shaykh.

'UthmÂNî Muhammad Taqî, Abkâmul-I'tikâf (Urdu - The commandments of seclusion), Karachi [n.d.]

ZAKARÎY Muhammad 1975 (1940), Tablìghî Nisâb (Urdu - Course on the propagation of Islam), Delhi, Madîna Book Depot; later editions: Fadâ'il-i A'mâl (Urdu - The Virtues of [Correct] Religious Practices). Delhi, Idâra-i Dînîyât.

ZAKARIYÂ Muhammad, 1993, Ap bîtî: autobiography of Quthbu'l-Aqthâb Shaykhu'lHadîth Hadhrat Maulânâ Muhammad Zakariyya Kandhlawi (Rabmatullab Alaybi) 2 vols., Delhi, Idara Isha'at Diniyat. 
50 - Archives de sciences sociales des REligions

\section{Résumé}

L'article discute les résultats d'un travail de terrain en Inde et au Pakistan portant sur l'influence de pratiques et de concepts liés au soufisme dans le fonctionnement du Tablìghî Jamâ'at. Il s'agit là d'observations préliminaires, dans la mesure où le projet et le travail de terrain n'étaient pas axés spécifiquement sur la question des rapports avec le Soufisme mais sur les conceptions sociales et organisationnelles des Tablîghîs. Afin d'organiser les observations du terrain, l'article se concentre sur trois points : comment la direction et l'orientation religieuse personnelles sont construites sur le modèle du Soufisme; comment l'interaction et l'auto-organisation à différents niveaux de prise de décision dans le Tablìghî Jamâ'at sont modelés sur un ordre soufi; comment la spiritualité soufie est utilisée dans les rituels et la philosophie Tablîghî pour mobiliser les adhérents. On signalera ensuite des influences opposées comme les variables locales entre les différentes sections en Inde, où l'on peut affirmer que l'héritage Soufi est plus fort, et au Pakistan, où l'héritage soufi est en passe de devenir "clandestin". En conclusion, on se demandera dans quelle mesure le succès de la Tablîghî Jamâ'at est fondé sur sa fusion réussie de ses antécédents soufis et réformistes.

Mots-clés : Tablîghî Jamâ'at, islam soufi, mouvements missionnaires, mouvements piétistes, Inde, Pakistan, tradition deoband en islam, réformisme islamique (Islah).

\section{Abstract}

The paper discusses the results of field research in India and Pakistan with regard to the influence of Sîfî-related practices and concepts in the workings of the Tablight Jamâ'at. These observations are of a preliminary nature, as the project and field research were not specifically focused on Sîfî connections but on the social and organisational worldview of the Tablighîs. To structure the observations from the field research, the presentation concentrates on three issues: how personal religious leadership and guidance are constructed on the Sûfî model; how interaction and selforganisation at various decision-making levels in the Tablighî Jamâ'at are modelled after a Sûfî order; how Sûfî spirituality is used in Tablîghî rituals and philosophy to mobilise adherents. It will then raise countervailing sing influences such as local variables between its branches in India, where the Sîfî legacy is arguably stronger, and Pakistan, where the Sûfî heritage is going "underground". In conclusion it will discuss as to what extent the success of the Tablighî Jamâ'at is rooted in its successful fusion of its Sîfî and reformist antecedents.

Key words: Tablìghî Jamâ'at, Sûfî̀ Islam, missionary movements, Pietist movements, India, Pakistan, Deoband tradition in Islam, Islamic reformism (Islah).

\section{Resumen}

El artículo discute los resultados de un trabajo de campo en India y en Pakistán centrado en la influencia de las prácticas y de los conceptos ligados al sufismo en el funcionamiento de la Tablìghî Jamâ'at. Se trata de observaciones preliminares, en la medida en que el proyecto y el trabajo de campo no estaban centrados específicamente en la cuestión de las relaciones con el Sufismo, sino en las concepciones sociales $y$ organizacionales de las Tablîghîs. Con el fin de organizar las observaciones de 
campo, el artículo se concentra en tres puntos : cómo la dirección y la orientación religiosa personal es construida sobre el modelo del sufismo ; cómo la interacción y la auto-organización en diferentes niveles de toma de decisión en la Tablighî Jamâ'at son modelados sobre un orden Sûfî; de qué maneras la espiritualidad Sûfî es utilizada en los rituales y la filosofía Tablighî para movilizar a los adherentes. Senalaremos luego influencias opuestas como las variables locales entre las diferentes secciones en India, donde se puede afirmar que la herencia Sûfî es más fuerte, y en Pakistán, donde la herencia Sûfî está en proceso de volverse "clandestina ". En conclusión, nos preguntaremos en qué medida el éxito de la Tablighî Jamâ'at está fundado sobre su fusión exitosa de sus antecedentes Sufis y reformistas.

Palabras claves: Tablighî Jamâ'at, islam sufí, movimientos misioneros, movimientos pietistas, India, Paquistaní, tradición deoband en Islam, reformismo islámico (Islah). 
